\title{
Laser Energy Transmission for a Wireless Energy Supply to Robots
}

\author{
Nobuki Kawashima and Kazuya Takeda \\ Kinki University \\ Japan
}

\section{Introduction}

The robot development is actively done as a very hopeful tool in many disciplines, however, right now, the robot is not used actually for practical use. It is clear that once it is actually used, it becomes very important how to keep supplying energy. The wireless energy supply is mandatory. In most cases, it is considered that the rechargeable battery is most easy to solve it, however, for example, in nuclear power plant accident or chemical weapon disaster due to terrorism, once the robot enters into the contaminated area, it is almost impossible to return for the battery recharging. The wireless energy transmission is mandatory.

Even for those robots working in the area where it is impossible or very difficult for a man to access but the robot can return for the refueling, the wireless energy transmission is required when, for example, the robot malfunctions and can not return. A long time operation is required for the trouble shooting and for repair.

Moreover, some important activities urgently needed may not allow the robot to return for the refueling, then the wireless energy transmission is also very useful.

To realize the wireless energy supply, either the microwave or the laser energy transmission is considered most hopeful. The microwave energy transmission has an advantage of higher energy conversion efficiency and can be used through the cloud, but it is not easy to concentrate the power in a small region. It is considered as a useful tool for the power transmission from the space power station (SPS) to the earth.

Laser is easy to focus the beam in a small area and the mirror can be used to transmit energy behind a blind corner. Due to the development of laser diodes (LD), a very compact laser transmitter system can be constructed. For the robot use, the laser is more advantageous over the microwave system.

\section{Examples of development of robots using laser energy transmission technology}

\subsection{Lunar ice exploration rover}

We have started the laser energy transmission technology development from 1997 to apply to a rover to explore the presence of ice in the bottom of craters in the lunar polar region, where no sun light is available. On the contrary, the solar radiation is always available at the periphery of the crater. The solar energy is converted into the electric energy and then to the 
laser light there and the laser beam is transmitted to the rover working at the bottom of the crater (Fig. 1) [1].

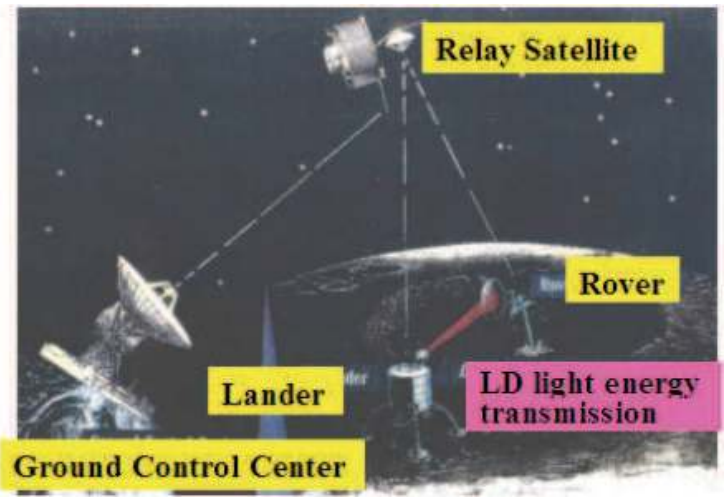

Fig. 1. Rover to explore to confirm the presence of ice on the moon using the laser energy transmission

A proto-type model has been constructed. The laser system consists of a $60 \mathrm{~W}$ Laser Diode system and the laser is output through a 400 micrometer fiber with NA=0.22. The laser light is focused on a $70 \mathrm{~cm}$ diameter receiving solar panel at the distance of $1 \mathrm{~km}$ using a mirror of $25 \mathrm{~cm}$ in diameter. The rover can easily be driven at the power more than $10 \mathrm{~W}$.

Though the lunar exploration mission based on this experiment is not yet realized as the actual space mission, the energy transmission to more than $1 \mathrm{~km}$ has successfully been done on the ground to drive an actual size rover with an conversion efficiency more than $20 \%$ (Fig.2) [2], [3].

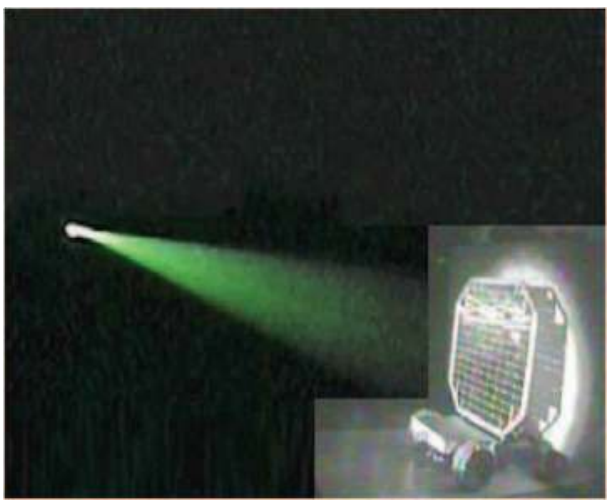

Fig. $2.1 \mathrm{~km}$ laser energy transmission to a model lunar rover has successfully been done

\subsection{Robot}

As a spin-off of the technology developed for the space mission described above, we have tried to apply the laser energy transmission system to an actual robot. The robot is constructed using the parallel mechanism (Fig. 3). Particular emphasis is put on the application to a rescue robot. 


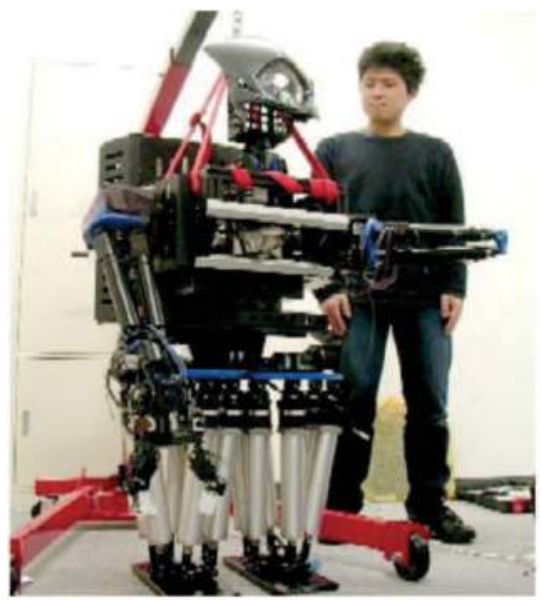

Fig. 3. Rescue robot partly powered by the laser

Currently, the power required to drive the robot itself is more than $120 \mathrm{~W}$ and the laser power can only drive the motion of an arm and fingers.

\subsection{Small aircrfts}

\subsubsection{Kite plane}

The laser energy transmission technology is also applied to the small aircraft for the surveillance of damaged areas and for the communication relay station at natural disaster such as flood, earthquake, volcano eruption etc.

First we have tried a kite plane as shown in Fig. 4. It is considered that the kite plane has a better flight stability in bad wind conditions compared with other small airplanes.

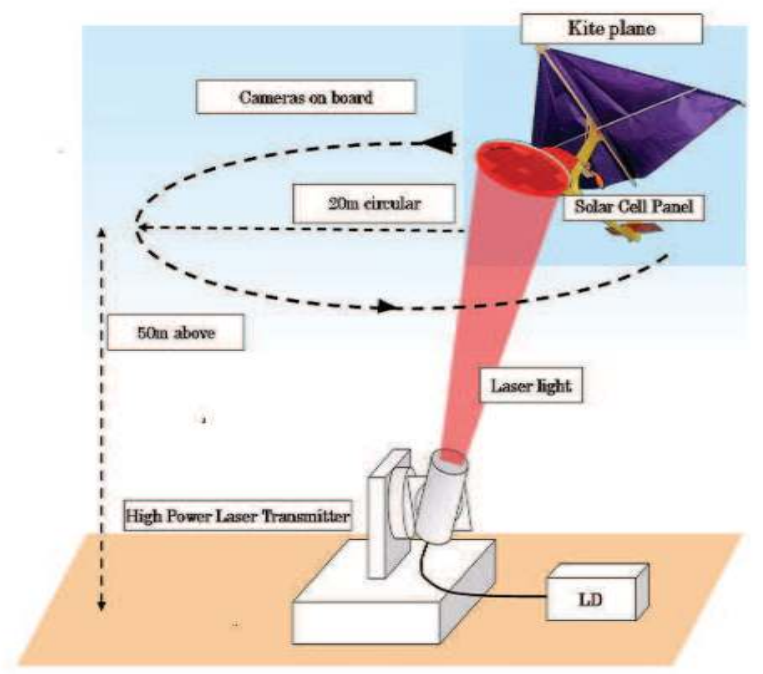

Fig. 4. System configuration of a laser energy driven kiteplane 
i) Kite Plane

The kite plane has a very simple structure. It is driven by a simple propeller in the center powered by an electric motor.

Other characteristics of the kite plane is shown below :

$\begin{array}{lllcll}\text { Length } & 789 \mathrm{~mm} & \text { Width } & 1,360 \mathrm{~mm} & \text { Height } & 560 \mathrm{~mm} \\ \text { Wing area } & 5000 \mathrm{~m}^{2} & \text { Weight } & 800 \mathrm{~g} & \text { Payload weight } & 600 \mathrm{~g}\end{array}$

The motion of the kite plane is controlled by an radio wave controller. A solar panel of 30 $\mathrm{cm}$ in diameter is placed underneath the plane. It consists of 30 small GaAs solar cells $(4 \mathrm{~cm} \mathrm{x}$ $7 \mathrm{~cm}$ ). 10 cells are connected in series and 3 in parallel and it is directly connected to the propella motor (Fig. 5).

The maximum output power is about $42 \mathrm{~W}$ when it is irradiated by a $200 \mathrm{~W}$ laser.

A small corner cube is set in the center of the panel to reflect a part of the laser beam to the transmitter. This is used to track the kite plane.

A small Li-Polymer battery ( $7.4 \mathrm{~V} 480 \mathrm{~mA} 36 \mathrm{~g}$ ) is used in parallel to maintain the necessary power during the take-off from the ground. It can sustain the kite plane flight less than 5 min.

A small TV camera (15 g with small battery and transmitter) is on board to observe the scene below.

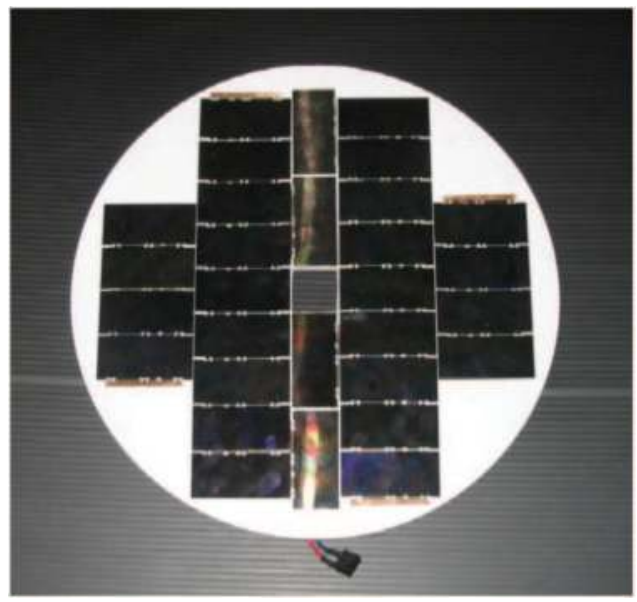

Fig. 5. Solar panel for a kite plane drive

ii) Laser System

Two fibre coupled $200 \mathrm{~W}$ laser diode transmitter are used. The wave length is $\lambda 808 \mathrm{~nm}$ and the light beam is coming out from a fibre whose core diameter is $400 \mu \mathrm{m}$ and the crad diameter $480 \mu \mathrm{m}$ with NA $=0.22 .15 \mathrm{~V} 39 \mathrm{~A}$ is required for $200 \mathrm{~W}$ laser output. One is cooled by a couple of Peltier cooling units (cooling capability is $255 \mathrm{~W}$ each) and the other is watercooled.

iii) Long Time Flight Test

A long time flight test was done at the baseball stadium "Osaka dome“ in early 2006. The kite plane was first flown from the ground using the on-board small battery and the orbit of the kite plane was controlled by a radio controller. When a level flight of an altitude of $50 \mathrm{~m}$ 
and a circular radius of $10 \mathrm{~m}$ was realized, the laser was focused to the solar panel on the kite plane. The laser power of $300 \mathrm{~W}(200 \mathrm{~W}+100 \mathrm{~W})$ was used and the power required was monitored and recorded on a on-board power monitor. The dome stadium has a ceiling height of $60 \mathrm{~m}$ and no appreciable wind is there. And a long time stable flight operation was successfully realized more than 1 hour in each cases. The time was limited by the availability of the dome.

The average power measured on board was about $40 \mathrm{~W}$. The flight performance was taken by CCD cameras as shown in Fig. 6, where the motion of the kite plane during the level flight of $10 \mathrm{~m}$ in diameter and $50 \mathrm{~m}$ in altitude.is shown. A zoomed image of the plane during the flight is shown in Fig. 7 with its shade on the ceiling of the dome [4].
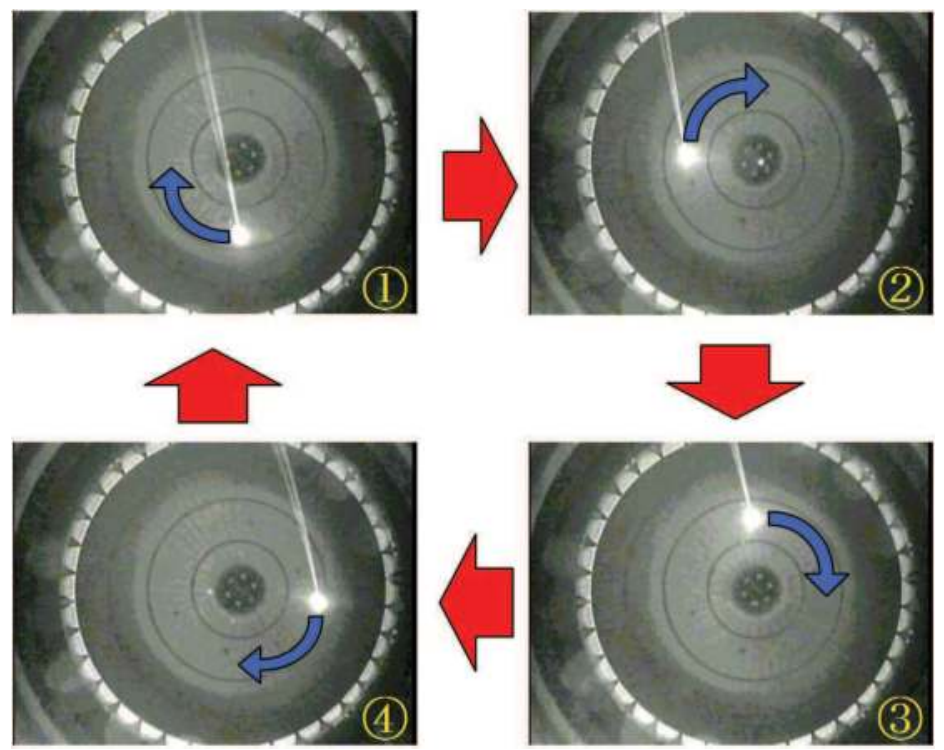

Fig. 6. Circular flight of a laser-light receiving kiteplane with a radius of $10 \mathrm{~m}$ and at an altitude of $50 \mathrm{~m}$

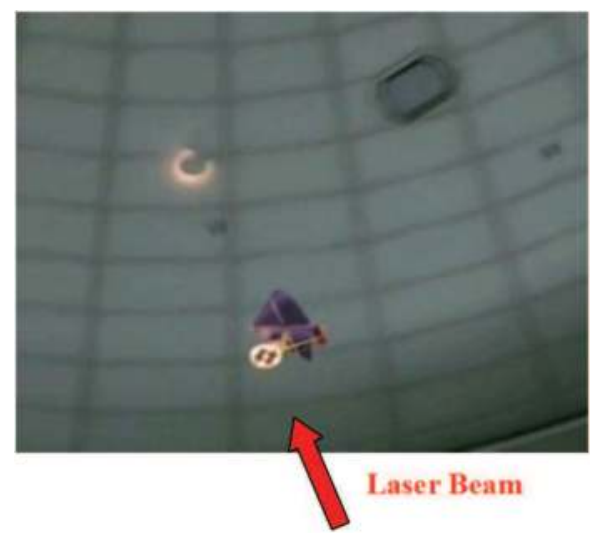

Fig. 7. Flying kite plane under the auto-tracking (The solar panel is irradiated by the laser light with its shade on the ceiling) 


\subsubsection{Helicopter}

The application of this laser driven airplane we aim is, as described above, to use it as a surveillance flight over the area where the human access is difficult in the case of natural disasters such as flood or earthquake. A long time flight can be realized and no return of the aircraft to the base for the refueling or recharging is required.

In order for this system to be used in real disaster cases, the horizontal range shall be increased, however, in the case of the kite plane with the current horizontally set solar panel, in order to increase the horizontal range, the vertical altitude shall also been increased. To reduce the vertical altitude, the solar panel shall be set vertically, then the attitude control of the solar panel conflicts with a stable spacecraft maneuver.

To solve this problem, the helicopter is the most appropriate and we can set the solar cell panel vertically (Fig. 8). However, the helicopter requires much more electric power than the airplane.

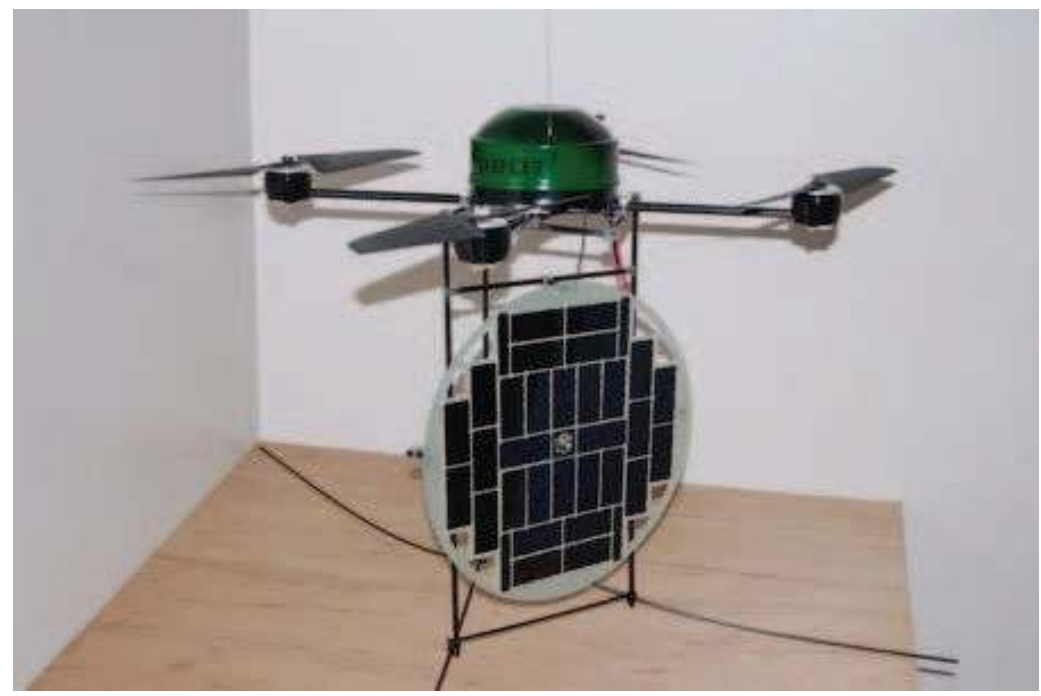

Fig. 8. Helicopter with a vertical solar panel underneath

One solution is to increase the laser power, then we need a more efficient cooling of the solar panel. The other solution is to increase the conversion efficiency from the laser power to the electricity.

For the former, we have increased the laser power up to $530 \mathrm{~W}$. The cooling of the solar panel is accomplished by setting it under the helicopter body. The wind generated by the propeller cools the panel.

For the latter, first we filled the panel with as many cells as possible on the panel. Since the shape of the solar cell commercially available is fixed, we tried to cut it in half. More improvement of the efficiency has been achieved by optimizing the cell connection. The detail of this improvement will be described elsewhere.

It has taken a long time try and error procedure and finally we have realized a stable long time flight. We use a small battery to maintain the safe landing of the helicopter even when the proper tracking of the laser receiving solar cell panel fails. We have confirmed that even after more than one hour flight, the battery maintains a full charging (Fig. 9) [5]. 


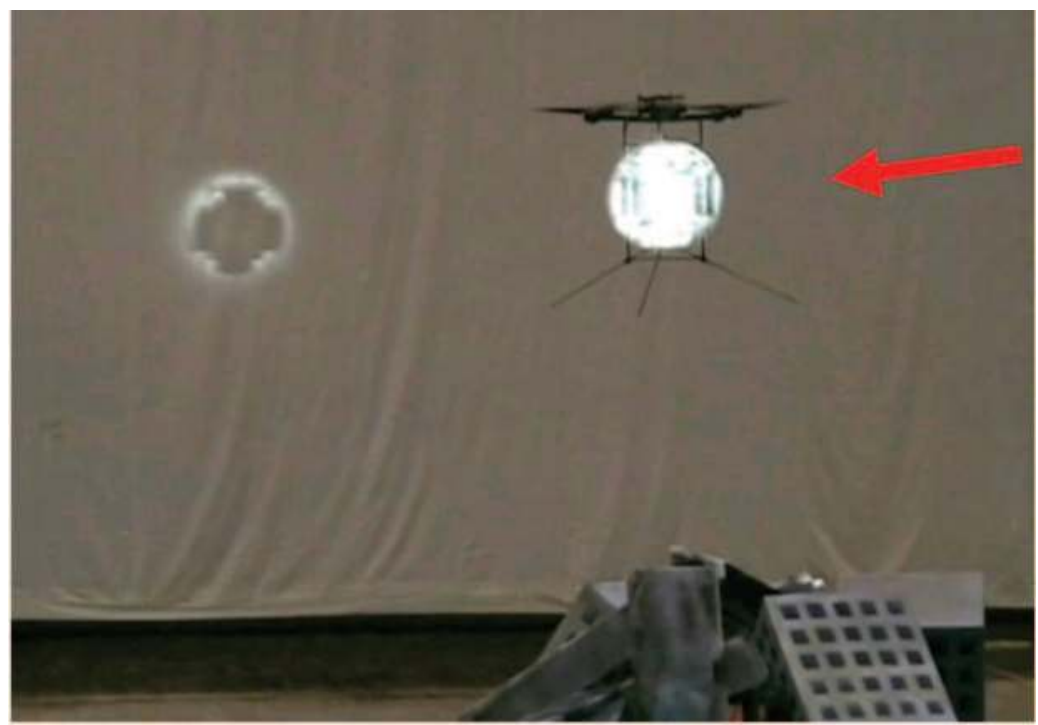

Fig. 9. Helicopter flight receiving the energy from the laser energy transmission over a simulated disaster ruin

\section{Problems to be solved}

a. Increase of the conversion efficiency of LD

The laser diode is very compact and have a high conversion efficiency more than $30 \%$, however, when the output power is more than hundred watts, the dissipated heat is quite large and the cooling system is not anymore compact. More increase of the conversion efficiency is strongly required.

b. Development of an efficient cooling system

Right now, for a laser diode of the power less than $100 \mathrm{~W}$, the Peltier cooling system can be used. For a higher power, the water cooling system is needed and it is not at all compact. More efficient compact cooling system is required.

c. Increase of the laser energy conversion efficiency of the solar cell to the electric energy We are now using a solar cell of single junction GaAs of Spectrolab Inc. U.S.A. having a single cell conversion efficiency more than $40 \%$. However, the overall efficiency of the solar panel is less than $25 \%$. The reason why is that there is an open space between cells on the panel and also the intensity distribution is not uniform so that all the cells cannot receive the laser light at the optimum operation condition. Some cell has an conversion efficiency more than $60 \%$ and higher efficiency cell is strongly needed.

\section{Conclusion}

We can find a lot of robot applications in construction activities, where it is very difficult or dangerous for a man to access and only robots can work. The time will come soon when the actual use of those robots is extensively realized and the wireless energy transmission technology using laser is a unique means to supply energy to those robots. 


\section{References}

N. Kawashima , "The importance of the development of a rover for the direct confirmation of the existence of ice on the moon, "Trans. Japan. Soc. Aeronaut. Space Sci. Vol.43, 2000, pp.34-35

K. Takeda, M. Tanaka, S. Miura, K. Hashimoto, N. Kawashima, H. Matsumoto, T. Goshozono, S. Ishi and J. Mizui, "Laser power transmission for the energy supply to the rover exploring ice on the bottom of the crater in the lunar polar region, "SPIE, Vol.4632, 2002, pp.199-223

N. Kawashima and K. Takeda, "1.2 km laser energy transmission for the development of a lunar rover confirming the presence of ice on the moon, " Proc. ILC 2003 / ILEWG 2004

N. Kawashima, K. Takeda and K. Yabe, "Application of the laser energy transmission technology to drive a small airplane" Chinese Optics Letters Vol 5 Suppl. 2007 S109-110

K. Takeda, N. Kawashima and K. Yabe, "Laser Energy Transmission to a Small-Unmanned Aerial Vehicle(in Japanese)" Uchu Gijutsu Vol 72008 pp.27-32 


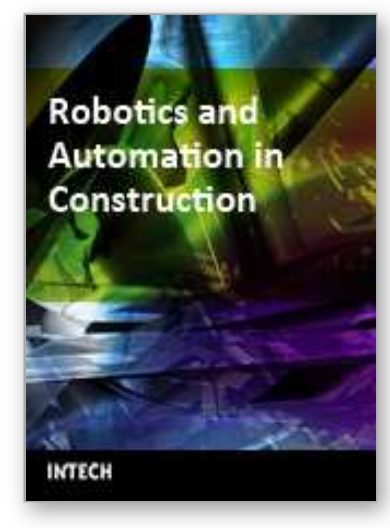

\author{
Robotics and Automation in Construction \\ Edited by Carlos Balaguer and Mohamed Abderrahim
}

ISBN 978-953-7619-13-8

Hard cover, 404 pages

Publisher InTech

Published online 01, October, 2008

Published in print edition October, 2008

This book addresses several issues related to the introduction of automaton and robotics in the construction industry in a collection of 23 chapters. The chapters are grouped in 3 main sections according to the theme or the type of technology they treat. Section I is dedicated to describe and analyse the main research challenges of Robotics and Automation in Construction (RAC). The second section consists of 12 chapters and is dedicated to the technologies and new developments employed to automate processes in the construction industry. Among these we have examples of ICT technologies used for purposes such as construction visualisation systems, added value management systems, construction materials and elements tracking using multiple IDs devices. This section also deals with Sensorial Systems and software used in the construction to improve the performances of machines such as cranes, and in improving Human-Machine Interfaces (MMI). Authors adopted Mixed and Augmented Reality in the MMI to ease the construction operations. Section III is dedicated to describe case studies of RAC and comprises 8 chapters. Among the eight chapters the section presents a robotic excavator and a semi-automated façade cleaning system. The section also presents work dedicated to enhancing the force of the workers in construction through the use of Robotic-powered exoskeletons and body joint-adapted assistive units, which allow the handling of greater loads.

\title{
How to reference
}

In order to correctly reference this scholarly work, feel free to copy and paste the following:

Nobuki Kawashima and Kazuya Takeda (2008). Laser Energy Transmission for a Wireless Energy Supply to Robots, Robotics and Automation in Construction, Carlos Balaguer and Mohamed Abderrahim (Ed.), ISBN: 978-953-7619-13-8, InTech, Available from:

http://www.intechopen.com/books/robotics_and_automation_in_construction/laser_energy_transmission_for_a _wireless_energy_supply_to_robots

\section{INTECH}

open science | open minds

\author{
InTech Europe \\ University Campus STeP Ri \\ Slavka Krautzeka 83/A \\ 51000 Rijeka, Croatia \\ Phone: +385 (51) 770447 \\ Fax: +385 (51) 686166
}

\author{
InTech China \\ Unit 405, Office Block, Hotel Equatorial Shanghai \\ No.65, Yan An Road (West), Shanghai, 200040, China \\ 中国上海市延安西路65号上海国际贵都大饭店办公楼 405 单元 \\ Phone: +86-21-62489820 \\ Fax: $+86-21-62489821$
}


www.intechopen.com 
(C) 2008 The Author(s). Licensee IntechOpen. This chapter is distributed under the terms of the Creative Commons Attribution-NonCommercialShareAlike-3.0 License, which permits use, distribution and reproduction for non-commercial purposes, provided the original is properly cited and derivative works building on this content are distributed under the same license. 